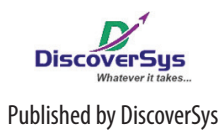

Published by DiscoverSys

\section{The Utilization of Reproductive Health Services for Adolescents in Tegallalang I Health Centre}

\author{
Deni Witari, ${ }^{1}$ Ni Luh Putu Suariyani, ${ }^{1,2}$ I Nyoman Mangku Karmayaa,
}

CrossMark

\section{ABSTRACT}

Background and purpose: Adolescence is one of the most crucial periods of a human's life cycle, and therefore, there is an unquestionable need for services that directly address adolescent reproductive health issues. The number of adolescents who utilized reproductive health services at Tegallalang I Health Centre is only 119 out of 708 targeted adolescents. This study investigate the correlation between knowledge, attitude, adolescent needs, access, family acceptability, and the utilization of reproductive health services in Tegallalang I Health Centre. Methods: The design was a cross sectional analytic. From the population of 4725 adolescents in the Tegallalang I Health Centre work area, 84 were selected through systematic random sampling. The independent variables were knowledge, attitude, adolescent needs, access and family acceptability while the dependent variable was the utilization of adolescent reproductive health service. Data was collected through structured interviews and analysed using univariate, bivariate (chi-squared test), and multivariate (logistic regression) analysis.

Results: The results of this study showed that most respondents have high level of knowledge (54.8\%), negative attitudes (69.0\%)), perceived need $(59.5 \%)$, ease of access $(52.4 \%)$, negative family acceptability (60.7\%)), and (62.0\%) do not take advantage of services. Based on the bivariate analysis it is evident that there is a relationship between knowledge ( $p=0.043)$, attitude $(p=0.047)$, access $(p=0.08)$, family acceptability $(p=0.042)$ and the utilization of reproduction health service. Based on multivariate analysis, it is evident that access has a positive influence on the utilization of reproductive health service with $0 \mathrm{R}=3.481$ (95\% Cl: 1,21-10,24).

Conclusion: Access has a positive influence on the utilisation of reproductive health service in Tegalalang I Health Centre.

\title{
Pemanfaatan Pelayanan Kesehatan Reproduksi Remaja di Wilayah Kerja Puskesmas Tegallalang I
}

\section{ABSTRAK}

Latar belakang dan tujuan: Masa remaja merupakan salah satu masa paling kritis dalam siklus kehidupan manusia, sehingga diperlukan pusat pelayanan kesehatan reproduksi remaja untuk memberikan bimbingan dan pelayanan kesehatan. Pemanfaatan pelayanan kesehatan reproduksi di Puskesmas Tegallalang I sangat rendah yaitu 119 remaja (16,8\%) dari 708 yang ditargetkan. Penelitian ini bertujuan untuk mengetahui hubungan karakteristik remaja, akses dan akseptabilitas keluarga dengan pemanfaatan layanan kesehatan reproduksi di wilayah kerja Puskesmas Tegallalang I.

Metode: Desain penelitian adalah cross sectional analitik. Populasi penelitian adalah remaja di wilayah kerja puskesmas sebanyak 4725 orang dengan jumlah sampel 84 orang. Sampel dipilih secara systematic random sampling. Variabel bebas meliputi pengetahuan, sikap, akses dan akseptabilitas keluarga sedangkan variabel terikatnya adalah pemanfaatan pelayanan kesehatan reproduksi. Data dikumpulkan dengan wawancara. Analisis data dilakukan secara univariat, bivariat (chi-squared test) dan multivariat (regresi logistik).

Hasil: Sebagian besar responden (54,8\%) memiliki pengetahuan tinggi, sikap negatif (69\%), memerlukan pelayanan (59,5\%), akses mudah (52,4\%), akseptabilitas keluarga negatif (60,7\%) dan tidak memanfaatkan pelayanan (62\%). Berdasarkan analisis bivariat diperoleh hubungan yang bermakna antara pengetahuan $(p=0,043)$, sikap $(p=0,047)$, akses $(p=0.08)$, akseptabilitas keluarga $(p=0,042)$ dengan pemanfaatan pelayanan kesehatan reproduksi. Pada analisis multivariat didapatkan akses memiliki kontribusi tertinggi yang berhubungan dengan pemanfaatan pelayanan kesehatan reproduksi dengan $0 \mathrm{R}=3,481$ (95\%(l: 1,21-10,24). Simpulan:Variabel akses berhubungan dengan pemanfaatan layanan kesehatan reproduksi di Puskesmas Tegalalang I. Program Udayana Univ Pepartment of Public Faculty of Medicine Udayana University,

${ }^{3}$ Department of Anatomy, Faculty of Medicine Udayana University

"Correspondence to:

dnoksaelus@yahoo.co.id
Kata kunci: remaja, pemanfaatan, pelayanan kesehatan reproduksi, puskesmas

Cite This Article: Witari, D., Suariyani, N.L.P., Karmaya, I.N.M. 2014. Pemanfaatan Pelayanan Kesehatan Reproduksi Remaja di Wilayah Kerja Puskesmas Tegallalang I. Public Health and Preventive Medicine Archive 2(1): 22-26. D01:10.15562/phpma.v2i1.118 


\section{PENDAHULUAN}

Masa remaja merupakan salah satu masa paling kritis dalam siklus kehidupan manusia. Hal ini mengakibatkan adanya kebutuhan terhadap pusat pelayanan kesehatan reproduksi (kespro) remaja untuk memberikan bimbingan dan pelayanan kespro. ${ }^{1} \quad$ Puskesmas merupakan penyedia pelayanan kepada masyarakat yang berada pada garis terdepan dan membantu mengatasi masalah kesehatan termasuk masalah kesehatan remaja. ${ }^{2}$

Sepanjang tahun 2012, dari total remaja yang ditargetkan yaitu sebanyak 708 orang yang memanfaatkan layanan kesehatan di Puskesmas Tegallalang I, hanya sebanyak 119 remaja (16,8\%) yang datang memanfaatkan layanan puskesmas. Remaja yang memanfaatkan pelayanan kesehatan puskesmas sebagian besar dengan masalah kesehatan fisik dan belum ada remaja yang secara sukarela berkonsultasi tentang kesehatan reproduksinya.

Rendahnya tingkat pemanfaatan pelayananan kesehatan reproduksi menurut WHO disebabkan oleh beberapa faktor: 1) faktor predisposisi, yaitu kurangnya pengetahuan, sikap yang negatif terhadap pemanfaatan pelayanan kespro, 2) faktor pendukung, yaitu kurangnya akses untuk mendapatkan informasi yang jelas, 3) faktor pendorong, yaitu pelayanan yang kurang bersahabat dengan remaja, akseptabilitas keluarga yang belum sepenuhnya menerima keberadaan pelayanan kespro remaja dan 4) faktor kebutuhan, yaitu kebutuhan remaja yang masih kurang memerlukan pemanfaatan pelayanan kespro. ${ }^{3}$

Penelitian ini bertujuan untuk mengetahui hubungan antara pengetahuan, sikap, kebutuhan remaja, akses dan penerimaan keluarga dengan pemanfaatan pelayanan kespro di puskesmas.

\section{METODE}

Desain penelitian adalah analitik cross sectional. Pengumpulan data dilaksanakan pada Bulan MaretApril 2013. Populasi penelitian adalah remaja yang berada di wilayah kerja Puskesmas Tegallalang I sebanyak 4725 orang. Sampel dipilih secara systematic random sampling sebanyak 84 orang.

Variabel bebas adalah pengetahuan, sikap, kebutuhan remaja, akses (keterjangkauan) dan penerimaan keluarga. Variabel terikat adalah pemanfaatan layanan kespro. Pengumpulan data dilakukan dengan wawancara di dua sekolah menengah atas yaitu SMA I dan SMKN I Tegallalang menggunakan kuesioner.

Variabel pengetahuan diukur dengan 10 pertanyaan (skor 0-10) dan dikategorikan menjadi pengetahuan rendah (nilai $<50 \%$ ) dan tinggi (nilai $\geq 50 \%$ ). Variabel sikap diukur dengan 7 pertanyaan, dengan rentang skor 0-7 dan variabel penerimaan diukur dengan 4 pertanyaan, rentang skor 0-4 kemudian dikategorikan menjadi negatif (nilai $<50 \%$ ) dan positif (nilai $\geq 50 \%$ ). Variabel kebutuhan remaja diukur dengan 4 pertanyaan, dengan rentang skor 0-4 dan dikategorikan menjadi tidak memerlukan pelayanan kespro (nilai $<50 \%$ ) dan memerlukan (nilai $\geq 50 \%$ ). Variabel akses diukur dengan 14 pertanyaan, rentang skor 0-14 dan dikategorikan menjadi akses sulit (nilai <50\%) dan mudah (nilai $\geq 50 \%$ ). Variabel pemanfaatan terdiri dari 4 pertanyaan dengan rentang skor 0-4 dan dikategorikan menjadi memanfaatkan pelayanan kespro (nilai <50\%) dan tidak memanfaatkan (nilai $\geq 50 \%$ ).

Analisis data dilakukan secara bertahap meliputi analisis univariat, bivariat dan multivariat. Analisis univariat dilakukan untuk melihat distribusi frekuensi masing-masing variabel. Analisa dilanjutkan dengan analisis bivariat untuk melihat hubungan antara variabel terikat dengan variabel bebas. Analisis multivariat dilakukan untuk mencari variabel bebas yang memiliki hubungan paling kuat dengan variabel terikat dengan kriteria pada analisis bivariat nilai $\mathrm{p}<0,25$.

Penelitian telah dinyatakan laik etik oleh Komisi Etik Penelitian Fakultas Kedokteran Universitas Udayana/Rumah Sakit Umum Pusat Sanglah Denpasar.

\section{HASIL}

Sebanyak 84 sampel yang terpilih dapat berpartisipasi dengan baik dalam penelitian ini dan tidak ada penolakan. Berdasarkan analisis univariat, diperoleh bahwa responden yang memiliki pengetahuan tinggi sebanyak 46 orang $(54,8 \%)$, memiliki sikap negatif sebanyak 58 orang (69\%), memerlukan pelayanan kespro sebanyak 50 orang $(59,5 \%)$, memiliki akses yang mudah 44 orang $(52,4 \%)$, penerimaan keluarga negatif sebanyak 51 orang $(60,7 \%)$ dan tidak memanfaatkan pelayanan kespro sebanyak 52 orang (62\%).

Berdasarkan analisis bivariat, beberapa variabel bebas meliputi pengetahuan, sikap, akses dan penerimaan keluarga memiliki hubungan yang signifikan dengan pemanfaatan pelayanan kesehatan $(p<0,05)$. Dari hasil analisis bivariat variabel pengetahuan, sikap, kebutuhan remaja, akses dan akseptabilitas keluarga yang dijumpai dengan $\mathrm{p}<0,25$ kemudian dilanjutkan dengan analisis multivariat (regresi logistik) yang hasilnya disajikan pada Tabel 2.

Tabel 2 menunjukkan hasil analisis multivariat dimana faktor akses (keterjangkauan) terlihat memiliki OR=3,523 (95\%CI: 1,211-10,244). Hal ini berarti bahwa dari beberapa variabel yang dianalisis secara multivariat hanya faktor akses yang terbukti 
Tabel 1 Hasil analisis bivariat hubungan karakteristik remaja, akses dan akseptabilitas keluarga dengan pemanfaatan pelayanan kesehatan reproduksi

\begin{tabular}{|c|c|c|c|c|c|}
\hline \multirow[b]{2}{*}{ Variabel } & \multicolumn{2}{|c|}{$\begin{array}{l}\text { Pemanfaatan Layanan } \\
\text { Kesehatan Reproduksi }\end{array}$} & \multirow[b]{2}{*}{$\begin{array}{c}\text { Crude } \\
\text { OR }\end{array}$} & \multirow[b]{2}{*}{$95 \% \mathrm{Cl}$} & \multirow[b]{2}{*}{ Nilai p } \\
\hline & $\begin{array}{l}\text { Tidak } \\
\mathbf{f}(\%)\end{array}$ & $\begin{array}{c}\text { Ya } \\
\mathbf{f}(\%)\end{array}$ & & & \\
\hline \multicolumn{6}{|l|}{ Pengetahuan } \\
\hline Rendah & $28(73,7 \%)$ & $10(26,3 \%)$ & 2,567 & $1,018-6,474$ & 0,043 \\
\hline Tinggi & $24(52,2 \%)$ & $22(47,8 \%)$ & & & \\
\hline \multicolumn{6}{|l|}{ Sikap } \\
\hline Negatif & $40(69 \%)$ & $18(31 \%)$ & 2,593 & $1,002-6,709$ & 0,047 \\
\hline Positif & $12(46,2 \%)$ & $14(53,8 \%)$ & & & \\
\hline \multicolumn{6}{|l|}{ Kebutuhan remaja } \\
\hline Tidak memerlukan pelayanan kespro & $24(70,6 \%)$ & $10(29,4 \%)$ & 1,886 & $0,748-4,757$ & 0,177 \\
\hline Memerlukan pelayanan kespro & $28(56 \%)$ & $22(44 \%)$ & & & \\
\hline \multicolumn{6}{|l|}{ Akses } \\
\hline Sulit & $30(75 \%)$ & $10(25 \%)$ & 3,000 & $1,186-7,589$ & 0,018 \\
\hline Mudah & $22(50 \%)$ & $22(50 \%)$ & & & \\
\hline \multicolumn{6}{|l|}{ Penerimaan keluarga } \\
\hline Negatif & $36(70,6 \%)$ & $15(29,4 \%)$ & 2,550 & $1,026-6,338$ & 0,042 \\
\hline Positif & $16(48,5 \%)$ & $17(51,5 \%)$ & & & \\
\hline
\end{tabular}

Tabel 2 Hasil analisis multivariat hubungan karakteristik remaja, akses dan akseptabilitas keluarga dengan pemanfaatan pelayanan kesehatan reproduksi

\begin{tabular}{lcccc}
\hline & & \multicolumn{2}{c}{ 95\%Cl } & \\
\cline { 3 - 4 } Variabel & Adjusted OR & Lower & Upper & Nilai p \\
\hline Pengetahuan & 1,259 & 0,429 & 3,696 & 0,675 \\
Sikap & 2,842 & 0,975 & 8,287 & 0,056 \\
Kebutuhan Remaja & 1,461 & 0,513 & 4,164 & 0,478 \\
Akses & 3,523 & 1,211 & 10,244 & 0,021 \\
Akseptabilitas & 2,067 & 0,691 & 6,176 & 0,194 \\
\hline
\end{tabular}

Nilai $R^{2}=0,221$

memiliki hubungan bermakna dan sebesar 3 kali kemungkinannya untuk memanfaatkan pelayanan kespro.

\section{DISKUSI}

Tidak ada hubungan yang signifikan antara pengetahuan dengan pemanfaatan pelayanan kespro di wilayah kerja Puskesmas Tegallalang I. Hasil penelitian ini tidak sesuai dengan hasil penelitian Stone ${ }^{4}$ yang menunjukkan ada hubungan yang signifikan antara pengetahuan dengan pemanfaatan pelayanan kespro remaja. Kurangnya pengetahuan mengenai ketersediaan pelayanan kespro remaja dan ketakutan bertemu dengan provider sehingga remaja merasa tidak perlu mengunjungi pelayanan kespro remaja.
Perilaku seseorang dapat dipengaruhi oleh faktor internal (person) dan faktor eksternal (environment). Pengetahuan adalah salah satu faktor internal yang dapat memotivasi seseorang untuk berperilaku memanfaatkan atau tidak memanfaatkan pelayanan kespro tetapi juga dipengaruhi oleh faktor lingkungan hal ini sesuai dengan teori social learning dari Bandura.

Sumber informasi tentang pelayanan kesehatan reproduksi remaja dalam penelitian ini sebagian besar adalah dari media massa $(61,9 \%)$ dan petugas kesehatan (27,4\%). Petugas puskesmas dalam programnya pelayanan kesehatan peduli remaja (PKPR) mensosialisasikan pelayanan kespro remaja dengan membentuk kesehatan reproduksi remaja (KRR) dari siswa organisasi siswa intra sekolah (OSIS), palang merah remaja (PMR) dan kelompok 
siswa peduli AIDS dan Narkoba (KSPAN) untuk memberikan pembinaan, penyuluhan tentang kespro, narkoba, HIV/AIDS dan gizi remaja. Tujuan dari program ini adalah untuk meningkatkan pengetahuan, sikap dan perilaku positif terkait pemanfaatan pelayanan kespro. Hasil penelitian ini menunjukkan ada siswa yang memiliki pengetahuan tinggi namun tidak diikuti dengan pemanfaatan layanan yang baik. Tidak semua siswa mengikuti organisasi tersebut diatas sehingga banyak siswa yang tidak mengetahui dan paham mekanisme untuk memanfaatkan pelayanan kespro di puskesmas. Masih banyak remaja merasa malu, takut dan belum merasakan perlu untuk memanfaatkan pelayanan kespro. Dalam penelitian ini terlihat pula bahwa tidak ada hubungan antara sikap dengan pemanfaatan pelayanan kespro di wilayah kerja Puskesmas Tegallalang I. Hasil penelitian ini berbeda dengan penelitian Belmonte $^{6}$ dimana sikap berhubungan dengan keinginan remaja mengunjungi pelayanan kespro. Hal ini menunjukkan remaja di Bolivia memaknai pemanfaatan pelayanan kespro adalah bagi remaja yang telah melakukan hubungan seksual. Hal ini memengaruhi keinginan untuk mengunjungi pelayanan kesehatan tersebut. Sikap adalah predisposisi untuk berpikir, merasakan dan bertindak dengan cara tertentu terhadap objek yang ada. Kemampuan melakukan penilaian terhadap sistem pelayanan kesehatan yang ada akan menimbulkan sikap penerimaan atau penolakan terhadap pemanfaatan pusat pelayanan kesehatan reproduksi remaja. ${ }^{5}$ Sikap negatif remaja tentang pelayanan kesehatan kespro dapat disebabkan adanya anggapan remaja bahwa pelayanan kespro adalah untuk remaja bermasalah, kehamilan tidak diinginkan (KTD) dan pengguna narkoba sehingga remaja takut memanfaatkan pelayanan tersebut. Sebagian besar remaja mengharapkan diberikan pelayanan kesehatan yang terpisah dari orang sakit, orang dewasa dan ada jam khusus remaja. ${ }^{7}$

Tidak adanya hubungan antara kebutuhan remaja dengan pemanfaatan pelayanan kespro juga terlihat dalam penelitian ini. Remaja pada umumnya memiliki fisik yang relatif sehat sehingga remaja kurang memiliki kesadaran dan kurang mengerti akan kebutuhan kespro sebelum terbentur masalah terlebih dahulu. Hal ini sejalan dengan penelitian Kamau8 bahwa remaja tidak memanfaatkan pelayanan kespro karena remaja merasa sehat dan tidak perlu untuk mengakses dan memanfaatkan pelayanan kesehatan. Puskesmas Tegallalang 1 dengan program PKPR sudah memiliki tim khusus dan ruangan khusus bagi pelayanan kespro remaja. Saat ini remaja yang berkunjung ke puskesmas baru sebatas keluhan fisik dan belum ada secara sukarela untuk berkonsultasi tentang kespro. Rendahnya pemanfaatan ini kemungkinan karena remaja belum memahami kebutuhannya serta adanya pandangan dan sikap yang negatif. Tidak adanya hubungan antara kebutuhan remaja dengan pemanfaatan pelayanan kespro dalam penelitian ini tidak sejalan dengan penelitian di Kanada yang menemukan bahwa ada hubungan antara kebutuhan remaja dengan pemanfaatan pelayanan kesehatan remaja. Penyebab utama remaja memanfaatkan pelayanan kesehatan adalah karena keluhan fisik dan kebutuhan psikologis. Salah satu tujuan remaja memanfaatkan pelayanan kesehatan adalah untuk mencari informasi tentang pendidikan reproduksi dan seksualitas. ${ }^{9}$ Pelayanan kespro yang diberikan kepada remaja akan lebih berhasil jika melibatkan sekolah karena sebagian besar waktu remaja ada di sekolah. Pelayanan yang diberikan harus lengkap dan dapat melayani remaja sesuai dengan kebutuhannya secara partisipatif. ${ }^{11}$

Akses (keterjangkauan) adalah satu-satunya variabel yang memiliki hubungan yang bermakna dengan pemanfaatan pelayanan kespro di wilayah kerja Puskesmas Tegallalang I. Penelitian ini sejalan dengan di Kota Pekanbaru yang menunjukkan ada hubungan yang bermakna antara akses pelayanan kesehatan dengan pemanfaatan pelayanan kespro, walaupun persentase remaja yang mengaku akses pelayanan kesehatan mudah lebih banyak yang tidak memanfaatkan pelayanan kespro dibandingkan dengan yang memanfaatkan. ${ }^{12}$ Pemanfaatan pelayanan kesehatan yang dilengkapi dengan fasilitas yang baik dan mudah diakses biasanya lebih tinggi. ${ }^{13}$ Akses (keterjangkauan) pelayanan kesehatan tidak hanya mencakup kemampuan secara fisik untuk menjangkau pusat pelayanan dan waktu tempuh yang diperlukan untuk mengakses secara langsung, tetapi juga melibatkan ekonomi, psikologis, pengamatan serta persepsipersepsi potensial klien, termasuk informasi yang pernah diterima klien. Informasi tentang kespro merupakan bagian dari pelayanan kespro yang diperlukan oleh remaja. ${ }^{14}$ Kunjungan petugas puskesmas ke sekolah untuk mensosialisasikan pusat pelayanan kespro remaja di puskesmas dan memberikan informasi tentang kespro dalam usaha mendekatkan pelayanan kesehatan kepada remaja agar dapat diakses. Petugas puskesmas juga mensosialisasikan pelayanan kesehatan yang dapat diberikan di puskesmas. Puskesmas merupakan tempat pelayanan kesehatan satusatunya yang menjangkau sampai ke pelosok, sehingga merupakan tempat paling strategis untuk pelayanan kespro remaja dengan model pelayanan yang sesuai dengan kebutuhan remaja. Bagi siswa yang mempunyai masalah kesehatan, dianjurkan datang ke puskesmas untuk diberikan pelayanan kesehatan. Sosialisasi petugas puskesmas 
merupakan salah satu pengaruh kunjungan remaja ke puskesmas, walaupun kunjungan terbanyak baru sebatas remaja dengan masalah kesehatan fisik. Belum ada remaja yang secara sukarela memanfaatkan pelayanan kespro untuk tujuan konsultasi.

Tidak ada hubungan yang bermakna antara penerimaan keluarga dengan pemanfaatan pelayanan kespro di wilayah kerja Puskesmas Tegallalang I. Pelayanan kespro remaja akan meningkat pemanfaatannya jika mendapat dukungan dari keluarga. Semakin banyak masyarakat tahu tentang pentingnya kespro remaja, keberadaan pusat pelayanan kespro remaja akan semakin diterima masyarakat. Hal ini diharapkan meningkatkan pemanfaatan pelayanan kespro oleh remaja. 3 Hasil penelitian ini sejalan dengan hasil penelitian di Pekanbaru bahwa penerimaan keluarga tidak mempengaruhi remaja untuk memanfaatkan pelayanan kespro. ${ }^{12}$ Tingkat kebutuhan akan hak-hak kespro remaja demikian tinggi, serta adanya pandangan yang keliru tentang seksualitas dan kespro. Namun pelayanan dan konseling yang berkaitan dengan hal tersebut belum sepenuhnya dapat diterima masyarakat. Orang tua adalah sumber utama informasi, tapi orang tua merasa kurang punya informasi, malu membahas topik ini, dan tidak setuju bila remaja berminat mengetahui masalah seksualitas. ${ }^{16}$ Peran orang tua untuk memberikan informasi kespro belum banyak dilakukan. Sebagian orang tua merasa bahwa pemberian informasi dapat berakibat merangsang keinginan berhubungan seksual. ${ }^{7}$ Memperluas akses informasi tentang seksualitas dan kespro yang benar dan jujur bagi remaja akan membuat remaja makin sadar terhadap tanggung jawab perilaku reproduksinya. Lebih lanjut remaja akan mampu membuat keputusan dalam perilaku reproduksi remaja. $^{18}$

\section{SIMPULAN}

Faktor akses berhubungan secara statistik terhadap pemanfaatan pelayanan kespro. Variabel yang tidak terbukti berhubungan dengan pemanfaatan pelayanan kespro adalah pengetahuan, sikap, kebutuhan remaja dan penerimaan keluarga.

\section{UCAPAN TERIMA KASIH}

Ucapan terima kasih penulis sampaikan kepada Kepala Dinas Kesehatan Kabupaten Gianyar yang telah memberikan ijin penelitian, Kepala Puskesmas Tegallalang I, Kepala Sekolah SMA I dan SMKN I Tegallalang serta semua rekan yang membantu terselesainya penelitian ini.

\section{DAFTAR PUSTAKA}

1. Perdede N. Remaja dalam tumbuh kembang anak dan remaja, Ikatan Dokter Anak Indonesia. Jakarta: Sagung Seto; 2008.

2. Wilopo SA. Panduan pembinaan dan pengembangan pusat informasi dan konsultasi kesehatan reproduksi remaja. Jakarta: BKKBN; 2005.

3. WHO. Adolescent-friendly health services in the SouthEast Asia Region. Report of a Regional Consultation, Bali, Indonesia. New Delhi: WHO Regional Office for SouthEast Asia; 2004.

4. Stone and Igham. When and why do young people in the United Kingdom first use sexual health services? Perspectives on Sexual and Reproductive Health 2003; 35(3): 114-120.

5. Azwar S. Sikap manusia teori dan pengukurannya. Edisi ke 2. Yogyakarta: Pustaka Pelajar; 2003.

6. Belmonte, Gutierrez, Magnani, \& Lipovsek. Barriers to adolescents. 2000.

7. Berhane F, Berhane Y, Fantalun M. Adolescents' health service utilization pattern and preferences: consultation for reproductive health problems and mental stress are less likely. Ethiop.J.Health Dev 2005; 19(1): 29-36.

8. Kamau AW. Factors Influencing Access and Utilization of Preventive Reproductive Health Services by Adolescent in Kenya (Dissertation). University of Bielefeld; 2006.

9. Vingilis E, Wadeb T. \& Seeleya J. Predictors of Adolescent Health Care Utilization. Journal of Adolescent 2007; 30: 773-800.

10. Mc Pherson A. Adolescent in primary care. BMJ 2005; Vol.330: 455-467.

11. BKKBN, Tumbuh kembang remaja. 2004. Available from: http://www.bkkbn go.id (Akses 15 Nopember 2012).

12. Deswina. Faktor-faktor yang mempengaruhi rendahnya pemanfaatan pelayanan reproduksi remaja di Pekanbaru. 2008.

13. Barge S, Khan WN, Narvekar S \& Venkatachalam Y. Accessibility and utilization. 2003. Available from: http:// www.india_seminar.com/2003/532/532 sandhya barge et al.htm [Accessed 21 November 2012].

14. Thang NM, Anh DN. Accessibility and use of contraceptives in Vietnam. Internasional Family Planning Perspectives 2002; 28(4): 214-219.

15. WHO. Adolescent friendly health services - An agenda for change. Available from: <http://www.who.int/ childadolescent-health> [Accessed 12 November 2012].

16. Outlook. Kesehatan reproduksi remaja: membangun perubahan yang bermakna. Outlook 2000. 16:1-8

17. Munthali AC, Chimbiri A, Zulu E. Adolescent sexual and reproductive health in Malawi: A synthesis of research evidence. Occasional Report. New York \& Washington: The Alan Gutimacher Institute; 2004.

18. Tafal. Kebutuhan akan informasi dan pelayanan kesehatan reproduksi remaja. Jakarta: PKBI; 2006.

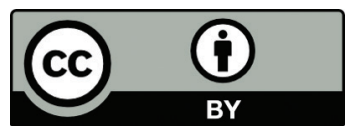

This work is licensed under a Creative Commons Attribution 